\title{
Syarat Diversi pada Anak yang Berkonflik dengan Hukum dalam Konsep Pemidanaan
}

\author{
Diversion Terms in Children Conflict with the Law in the Criminal Concept
}

\author{
Muhammad Sidrat \\ Lembaga Bantuan Hukum Generasi Muda Pemerhati Hukum (GEMPAH) \\ E-mail: Muhammad.sidrat21@gmail.com \\ Sabrina Hidayat \\ Pascasarjana Universitas Halu Oleo \\ E-mail: sabrina.hidayat54@yahoo.com \\ Herman \\ Pascasarjana Universitas Halu Oleo \\ E-mail: hermanmurhum2009@gmail.com
}

\begin{abstract}
Diversion is part of the concept of punishment based on the principle of child protection. Therefore, the principles contained in The Beijing Rules and Article 5 Paragraph (3) of the Child Criminal Justice System in Indonesian requires diversion efforts on children in conflict with the law. So that in the attempt to diversify children who are in conflict with the law, they should not prioritize diversion conditions where diversion will only be carried out when the criminal threat is under 7 years. Diversion must be given as an initial treatment of the conflict child before the determination of punishment. Child punishment must be in accordance with the child's condition and have beneficial consequences for the child.
\end{abstract}

Keyword: Diversion terms, concept of punishment, children conflict

Abstrak: Diversi merupakan bagian dari konsep pemidanaan dengan berlandaskan pada prinsip perlindungan anak. Oleh karena itu, Prinsip-prinsip yang termuat di dalam The Beijing Rules dan Pasal 5 Ayat (3) Undang-Undang Sistem Peradilan Pidana Anak di Indonesia mewajibkan adanya upaya diversi pada anak yang berkonflik dengan hukum. Sehingga dalam upaya diversi pada anak yang berkonflik dengan hukum sebaiknya tidak mengedepankan syarat diversi yang dimana diversi hanya akan dilakukan ketika ancaman pidananya di bawah 7 Tahun. Diversi harus diberikan sebagai penanganan awal terhadap anak yang berkonflik sebelum penentuan pemidanaan. Pemidanaan anak harus sesuai dengan keadaan anak dan menimbulkan konsekuensi bermanfaat terhadap anak.

Kata kunci: syarat Diversi, Konsep pemidanaan, anak yang berkonflik 


\section{PENDAHULUAN}

Permasalahan anak perlu mendapat perhatian ekstra demi terbentuknya anak sebagai generasi penerus yang bebas tindak pidana atau terhindar dari dampak negatif perkembangan teknologi di era globalisasi. Anak merupakan bagian dari generasi muda, sebagai salah satu sumber daya manusia yang merupakan potensi dan penerus cita-cita perjuangan bangsa di masa yang akan datang yang memiliki peran serta ciri-ciri khusus serta memerlukan pembinaan dan perlindungan yang khusus pula. ${ }^{1}$

Peran seorang anak sebagai satu-satunya penerus bangsa telah membawa hak-hak anak yang ada di Indonesia dan secara tegas dinyatakan dalam berbagai aturan. Hak anak yang dimaksud adalah suatu kehendak yang dimiliki oleh anak yang dilengkapi dengan kekuatan (macht) dan yang diberikan oleh sistem hukum/tertib hukum kepada anak yang bersangkutan. ${ }^{2}$ Anak sebagai bagian dari generasi muda merupakan penerus cita-cita perjuangan bangsa dan merupakan sumber daya manusia bagi pembangunan Indonesia ke depan, sehingga perlunya langkah-langkah strategis untuk melakukan perlindungan anak dari segi hukum. Sepanjang penggunaan sarana di luar sistem Peradilan pidana dipandang lebih efektif, maka proses peradilan pidana diupayakan untuk dihindarkan. Alasan dasarnya karena pengadilan akan memberikan stigmatisasi terhadap anak atas tindakan yang dilakukannya seperti anak dianggap jahat, sehingga lebih baik untuk menghindarkannya ke luar sistem peradilan pidana. ${ }^{3}$ maka dalam perjalanannya hukum anak di Indonesia diatur dengan berlandaskan pada konsep diversi.

Pada kenyataannya diversi belum sepenuhnya menyatukan konsep pemidanaan anak yang utuh demi kepentingan terbaik anak. Ketika anak yang melakukan tindak pidana dalam hal ini melakukan tindak pidana pengulangan (residiv), jelas anak harus menjalani pemidanaan karena diversi hanya dilaksanakan dalam hal tindak pidana yang dilakukan itu diancam dengan pidana penjara di bawah 7 (Tujuh) tahun dan bukan merupakan pengulangan tindak pidana. ${ }^{4}$ Menjadi tidak konsisten apabila tujuan diversi adalah menghindarkan anak dari proses peradilan, dan hasil kesepakatan diversi yang dianggap

1 Nashriana. Perlindungan Hukum Pidana Bagi Anak di Indonesia. Jakarta: PT. Grafindo Persada, 2011. hlm. 76

2 Maulana Hassan Wadong. Advokasi dan Hukum perlindungan Anak. Jakarta: PT Gramedia Widiasarana Indonesia, 2000. hlm. 29

3 Kenneht Folk. Early Intervention, Diversion and Youth Conferencing, A National Review of Current Approach to Diverting Juvenile from the Criminal Justice System. Canberra: Commonwealth of Australia. Government Attorney-general's Departement. 2003. hlm. 16.

4 Pasal 7 Ayat (1) Undang-Undang Nomor 11 Tahun 2012 Tentang Sistem Peradilan Pidana Anak. 
dapat memberikan konsekuensi terbaik bagi anak justru ada pembatasan diversi terhadap anak yang mengulangi tindak pidana dan terhadap anak yang diancam dengan pidana penjara 7 tahun atau di atas 7 tahun sementara landasan awal terbentuknya konsep diversi adalah untuk mencari kepentingan terbaik anak.

Oleh karena itu diperlukan pemahaman prinsip dari konsep diversi dan konsep pemidanaan yang sejalan dengan hak-hak anak sebagai tahap penetapan sanksi dalam hukum pidana anak. Penelitian ini menawarkan solusi kepada aparat penegak hukum untuk menangani perkara-perkara anak dimana dengan pemahaman mengenai prinsip hukum yang termuat dalam konsep diversi dan konsep pemidanaan dapat menjadi solusi terhadap upaya diversi pada anak yang terkendala karena adanya syarat diversi.

\section{METODE PENELITIAN}

Tipe penelitian ini tipe penelitian normatif. Penelitian hukum normatif adalah suatu proses untuk menemukan suatu aturan hukum, prinsip-prinsip hukum, maupun doktrindoktrin hukum untuk menjawab permasalahan hukum yang dihadapi. ${ }^{5}$ Penelitian ini dilakukan untuk menemukan prinsip-prinsip hukum dalam konsep diversi dan konsep pemidanaan. Penemuan prinsip hukum tersebut kemudian dijadikan landasan untuk menilai persyaratan upaya diversi pada anak yang berkonflik dengan hukum.

\section{ANALISIS DAN PEMBAHASAN}

\section{Dasar Yuridis Dan Ketentuan Upaya Diversi}

Ketentuan mengenai anak dalam Undang Sistem Peradilan Pidana terdapat pada pasal 1 angka 2 sampai angka 5. Anak yang berhadapan dengan Hukum adalah anak yang berkonflik dengan hukum anak yang menjadi korban tindak pidana dan anak yang menjadi saksi tindak pidana. Sementara anak yang berkonflik dengan hukum yang selanjutnya disebut anak adalah anak yang telah berumur 12 (dua belas) tahun, tetapi belum berumur 18 (delapan belas) tahun yang diduga melakukan tindak pidana. ${ }^{6}$ Mengenai anak di Indonesia dengan perkembangan hukumnya telah mengatur sistem Peradilan pidana anak. Sebelumnya sistem Peradilan pidana di Indonesia diatur dalam Kitab Undang-Undang

Peter Mahmud Marzuki. Penelitian Hukum. Jakarta: Kencana, 2008. hlm. 35

6 Angger Sigit Pramukti \& Fuady Primaharsya. Sistem Peradilan Pidana Anak. Jakarta: Media Pressindo. $2018 \mathrm{hlm} .42$ 
Hukum acara Pidana (KUHAP) dimana hukum acara pidana sering disebut juga dengan hukum pidana formal.

Dasar yuridis dalam hal menanggapi anak yang melakukan tindak pidana yakni terdapat Pasal 28B ayat (2) UUD Negara Republik Indonesia 1945 sebagai landasan menyatakan bahwa setiap anak berhak atas kelangsungan atas hidup, tumbuh dan berkembang, serta berhak atas perlindungan dan diskriminasi. Hal ini dijabarkan dalam UU Nomor 39 Tahun 1999 tentang Hak Asasi Manusia, Undang-Undang Nomor 23 Tahun 2002 tentang Perlindungan Anak dan yang mengatur sistem Peradilan anak terdapat dalam Undang-Undang Nomor 11 Tahun 2012.

Pelaksanaan penyidikan penuntutan, pemeriksaan pengadilan dan pelaksanaan putusan dimuat dalam sistem Peradilan pidana anak memiliki kesamaan dengan peradilan pidana pada umumnya namun pada pelaksanaannya diperlukan pejabat khusus untuk menangani perkara anak, dan syarat menghormati dan menjunjung tinggi harkat dan martabat anak dan Penahanan anak dari masa Penyidikan hingga ke tingkat kasasi jika perlu diusahakan atau diupayakan atau dilaksanakan dengan waktu yang singkat. Pelaksanaan diversi hanya sampai pada tahap pemeriksaan pengadilan hal ini tertuang dalam ketentuan pasal-pasal, mulai dari Pasal 5 sampai dengan Pasal 14, Pasal 29, Pasal 42 dan Pasal 52 ayat (2) sampai dengan ayat (6) Undang-Undang Nomor 11 Tahun 2012 tentang Sistem Peradilan Pidana Anak. Wajib mengupayakan Diversi pada tingkat penyidikan, penuntutan, dan pemeriksaan perkara anak di pengadilan dengan mengutamakan pendekatan Keadilan Restoratif. Diversi dilaksanakan mengutamakan kepentingan terbaik anak atau dengan kata lain upaya ini lebih mengarah pada perlindungan anak dimana pada tahap penyidikan haruslah dilaksanakan oleh pejabat khusus. Proses penangkapan harus memperhatikan kategori umur. Penahanan anak dititipkan dilembaga khusus anak. Biaya dibebankan oleh negara dan Pemeriksaan pengadilan juga harus dilakukan oleh hakim khusus.

\section{Diversi Berdasarkan Konsep Pemidanaan}

Kata diversi berasal dari bahasa Inggris diversion yang bermakna penghindaran atau pengalihan, diversi adalah pemberian kewenangan kepada aparat penegak hukum untuk mengambil tindakan-tindakan kebijakan dalam menangani atau menyelesaikan masalah pelanggaran anak dengan tidak mengambil jalan formal antara lain menghentikan atau 
tidak meneruskan dari proses peradilan pidana atau mengembalikan kepada masyarakat. ${ }^{7}$ Diversi pada anak adalah suatu pengalihan dengan syarat apakah meneruskan ke jalur formal proses Peradilan atau menghentikan dan atau mengembalikan kepada masyarakat. Kewenangan yang dapat menjalankan diversi tersebut diberikan kepada aparat penegak hukum.

Prinsip utama pelaksanaan konsep diversi yaitu tindakan persuasif atau pendekatan non penal dan memberikan kesempatan kepada seseorang untuk memperbaiki kesalahan. Petugas dalam melaksanakan diversi menunjukkan pentingnya ketaatan kepada hukum dan aturan. Petugas melakukan diversi dengan cara pendekatan persuasif dan menghindari penangkapan yang menggunakan tindakan kekerasan dan pemaksaan. ${ }^{8}$ Ini menekankan pada upaya untuk melakukan diversi yang dilakukan aparat penegak hukum dengan cara persuasif dan tanpa tindakan kekerasan pada saat melaksanakan penangkapan. Pada upaya komunikasi persuasif yang dibebankan pada petugas untuk menghindari tindakan kekerasan dan pemaksaan.

Secara umum diversi adalah pengalihan penanganan kasus-kasus anak yang diduga telah melakukan tindak pidana dari proses formal dengan atau tanpa syarat. Penanganan anak pelaku delinkuen sebagaimana dikehendaki dalam dengan Resolusi Perserikatan Bangsa-Bangsa (PBB) tentang United Nation Standard Minimum Rules for the Administration of Juvenile Justice, (The Beijing Rules). ${ }^{9}$ Upaya diversi dapat dilakukan dengan syarat ataupun tanpa syarat. Konsep diversi menjalankan suatu mekanisme yang memungkinkan anak dialihkan dari proses peradilan menuju proses pelayanan sosial.

Dengan demikian, diversi juga bermakna suatu upaya untuk mengalihkan anak dari proses yustisial menuju proses non yustisial dan mencari kepentingan terbaik anak. Upaya untuk mengalihkan proses Peradilan (pidana) anak menuju proses non Peradilan didasarkan atas pertimbangan bahwa keterlibatan anak dalam proses peradilan pada dasarnya telah melahirkan stigmatisasi. ${ }^{10}$ Untuk menghindari proses peradilan dan pengalihan lebih kepada proses pelayanan sosial dan melindungi anak dari stigmatisasi peradilan yang akan mengganggu mental anak. The definition of diversion is to find a

7 Marlina. Pengantar Konsep Diversi dan Restorative Justice dalam Hukum Pidana, Medan: USU Press. 2010. hlm. 3 .

8 Marlina. Diversi dan Restorative Justice Sebagai Alternatif Perlindungan Terhadap Anak Yang Berhadapan Dengan Hukum. Medan: Pusat kajian dan Perlindungan Anak, PKPA, hlm. 2007. 83.

9 M. Nasir Djamil. Anak Bukan Untuk Dihukum Catatan Pembahasan Undang-Undang Sistem Peradilan Pidana Anak (UU-SPPA), Jakarta: Sinar Grafika, 2013. hlm. 64.

10 Koesno Adi. Diversi Tindak Pidana Narkotika Anak. Malang: Setara Press, 2014. hlm. 122. 
solution by diverting problems that are directly related to the child from going outside the court (Definisi pengalihan adalah untuk menemukan solusi dengan mengalihkan masalah yang berhubungan langsung dengan anak menuju ke luar pengadilan). ${ }^{11}$ Diversi diupayakan untuk menemukan solusi terhadap anak diluar pengadilan.

Sejalan dengan pendapat Jack E. Bynum dalam bukunya Juvenile Delyquency a Sociologil Approch menyatakan: Diversion is an attempt to divert, or Chanel out, youthful offender from the juvenile justice system (Diversi adalah sebuah tindakan atau perlakuan untuk mengalihkan atau menempatkan pelaku tindak pidana anak keluar dari sistem Peradilan pidana). ${ }^{12}$ Pelaksanaan diversi menghindarkan penggunaan unsur pemaksaan untuk membuat orang menaati hukum, artinya prinsip keadilan di junjung tinggi dalam penegakan hukum tidak terkecuali saat penerapan prinsip-prinsip diversi yang dilaksanakan. ${ }^{13}$ Konsep diversi merupakan suatu pengalihan dengan syarat dari proses peradilan ke proses di luar pengadilan menuju proses pelayanan sosial yang dilakukan petugas dengan persuasif untuk menemukan solusi terbaik bagi anak atau untuk melindungi hak anak.

Selanjutnya untuk mengetahui diversi berdasarkan konsep pemidanaan, terlebih dahulu kita mengetahui apa itu tindak pidana dan pemidanaan itu sendiri. Menurut Pompe ${ }^{14}$ perkataan stafbaar feit itu secara teoritis dapat dirumuskan sebagai:

Suatu pelanggaran norma (gangguan terhadap tertib hukum) yang dengan sengaja ataupun tidak dengan sengaja telah dilakukan oleh seorang pelaku, di mana penjatuhan hukuman terhadap pelaku tersebut adalah perlu demi terpeliharanya tertib hukum dan terjaminnya kepentingan umum atau sebagai de normovertreding (verstoring der rechtsorde), waaran overtreder schuld heft en waarvan de bestraffing dienstig is voor de handhaving der rechts orde en de behartiging van het algemeen welzjin.

Pemidanaan merupakan pemberian putusan oleh hakim terhadap seseorang yang melakukan pelanggaran norma dengan sengaja ataupun tidak sengaja demi menjaga ketertiban umum. Van Hamel15menguraikan tindak pidana (straafbaar felt) itu sebagai Perbuatan manusia yang diuraikan oleh Undang-Undang, melawan hukum, strafwaardig

11 Oheo K, Haris. Victim's Involvement Model in Children Legal Process Based on Law No. 11/2012 on Children Criminal Justice System. Yuridika. Fakultas Hukum Universitas Airlangga. Volume 34 No. 1. 2019. https://e-journal.unair.ac.id/YDK/article/view/7943, diakses pada tanggal 8 Mei 2019, hlm. 109.

12 J. E. Bynum and W. E. Thompson, Juvenile Delinquency: A Sociological Approach (3rd. ed.). Needham Heights, MA: Allyn and Bacon. 1996, hlm. 430.

13 Marlina. Op.cit. hlm. 22.

14 P.A.F. Lamintang dan Theo Lamintang. Kejahatan Terhadap Nyawa, Tubuh, dan Kesehatan. Jakarta: Sinar Grafika, 2012. hlm. 182

15 Zainal Abidin. Analisis Eksistensial. Jakarta: Raja Grafindo Persada. 2007. hlm. 225 
(patut atau bernilai untuk dipidana), dan dapat dicela karena kesalahan (en aan schuld te witjen). Perbuatan pidana harus terdiri dari unsur-unsur lahiriah (fakta) oleh perbuatan adanya kelakuan serta akibat yang ditimbulkan karenanya. Dua hal tersebut yaitu kelakuan dan akibat. ${ }^{16}$ Andi Hamzah secara tegas memberi pengertian pemidanaan, adalah Penghukuman itu berasal dari kata dasar hukum, sehingga dapat diartikan sebagai menetapkan hukum atau memutuskan tentang hukumnya (berechten). ${ }^{17}$

Loebby Loqman, terdapat tiga kemungkinan dalam perumusan tindak pidana: pertama, tindak pidana dirumuskan dalam perumusan baik nama maupun unsurunsurnya. Kedua, adalah tindak pidana yang hanya dirumuskan unsurnya saja dan ketiga, tindak pidana menyebutkan namanya saja tanpa menyebutkan unsur-unsurnya. Bagi tindak pidana yang tidak menyebutkan unsur-unsurnya atau tidak menyebut namanya, maka serta unsurnya dapat diketahui melalui doktrin. ${ }^{18}$ Mengenai anak melakukan pelanggaran norma (gangguan terhadap tertib hukum) yang dengan sengaja ataupun tidak dengan sengaja dan harus dijatuhi pidana seusai dengan keadaan anak.

Jika dinilai dari tujuan diversi tersebut yang merupakan implementasi dari keadilan restoratif ialah berupaya mengembalikan pemulihan terhadap sebuah permasalahan, bukan sebuah pembalasan yang selama ini dikenal dalam hukum pidana. ${ }^{19}$ Menurut Robert M. Bohm, sasaran yang jelas harus tercapai dalam penerapan suatu diversi adalah menghindari anak terlibat dalam suatu proses peradilan pidana. ${ }^{20}$ Anak yang melakukan kejahatan diadili dan difasilitasi di tempat lain selain di pengadilan dengan tujuan agar anak tidak lagi melakukan tindak pidana dan menghindarkan anak dari stigma negatif.

Sejalan dengan tujuan program diversi yang merupakan sebuah sistem memberikan kesempatan yang lebih baik bagi para pelaku kejahatan, konsep diversi sebagai bentuk pengalihan atau penyimpangan kenakalan anak dari proses peradilan konvensional ke arah penanganan anak yang lebih bersifat pelayanan kemasyarakatan dan diversi dilakukan untuk menghindari anak pelaku dari dampak negatif praktik penyelenggaraan peradilan anak. Seperti yang dikemukakan Shanta B Singh dan Precious Nolwazi Ntuli menyebutkan:

Diversion is one of the fields aimed at channelling youth away from the criminal justicen system through reintegration programmes, provided that they take

\footnotetext{
16 Moeljatno. Asas-Asas Hukum Pidana (Edisi Revisi), Jakarta: Rineka Cipta, 2015. hlm. 64-69.

17 Tolib Setiady. Pokok-Pokok Hukum Penintesier Indonesia. Bandung: Alfabeta. 2010. hlm. 21.

18 Erdianto Effendi. Hukum Pidana Indonesia. Bandung: PT Refika Aditama, 2011. hlm. 99-100.

19 M. Nasir Djamil. Op.Cit, hlm. 64.

20 Robert \& Keith Haley. Introduction Criminal Justice. Callifornia-USA: Glencoe McGraw Hill, 2002. hlm. 494.
} 
responsibility for the crimes they committed. In certain circumstances, youth who have been in conflict with the law can be diverted to diversion programmes; as a result, they avoid a criminal record as well as the negative effects that can label them for life and damage their chances of obtaining employment in the future. ${ }^{21}$ (Pengalihan adalah salah satu bidang yang ditujukan untuk menyalurkan pemuda dari sistem justice kriminal melalui program reintegrasi, asalkan mereka bertanggung jawab atas kejahatan yang mereka lakukan. Dalam situasi tertentu, pemuda yang telah berkonflik dengan hukum dapat dialihkan ke program pengalihan; sebagai hasilnya, mereka menghindari catatan kriminal serta efek negatif yang dapat memberi label pada mereka seumur hidup dan merusak peluang mereka untuk mendapatkan pekerjaan di masa depan).

Pendapat tersebut mengungkapkan bahwa tujuan diversi secara umum untuk melindungi hak anak muda dimasa yang akan datang. Pendapat kedua Muntigh dan Shapiro:

Point out that diversion is one of the fields in which "rapid advances can be made in making the criminal justice system more humane and more effective (pengalihan atau diversi itu adalah salah satu bidang di mana kemajuan pesat dapat dibuat dalam membuat sistem peradilan pidana lebih manusiawi dan lebih efektif). ${ }^{22}$

Pendapat Muntigh dan Shapiro menilai tujuan diversi lebih mengefektifkan peradilan pidana. Artinya dalam Program diversi memberikan keuntungan pada masyarakat dalam penanganan yang awal dan cepat terhadap perilaku yang menyimpang. Penanganan awal ini juga menghemat biaya yang merupakan beban yang dikeluarkan oleh penegak hukum setempat. Tujuan diversi untuk menghindari penahanan, menghindari cap jahat/label sebagai penjahat, untuk meningkatkan keterampilan hidup bagi pelaku, agar pelaku bertanggungjawab atas perbuatannya, untuk mencegah pengulangan tindak pidana, untuk mengajukan intervensi-intervensi yang diperlukan bagi korban dan pelaku tanpa harus melalui proses formal, program diversi akan menghindari anak mengikuti proses-proses sistem peradilan anak. Langkah lanjut akan program ini akan menjauhkan anak-anak dari pengaruh-pengaruh dan implikasi negatif dari proses peradilan tersebut. ${ }^{23}$ Jeremy Bentham dalam pandangan teori Utilitarianisme, bahwa pemidanaan harus bersifat spesifik untuk tiap kejahatan dan kerasnya pidana tidak boleh melebihi jumlah yang diperlukan untuk mencegah dilakukannya penyerangan tertentu. Pandangan

21 B. Singh and Precious Nolwazi Ntuli. Diversion Programmes: Case Studies of the Youth Empowerment Scheme Programme at NICRO. Durban, South Africa, The Oriental Anthropologist, Vol. 17, No. 2, 2017. hlm. 259.

22 Ibid. hlm. 259

23 Setya Wahyudi. Implementasi Ide Diversi Dalam Pembaharuan Sistim Peradilan Pidana Anak di Indonesia. Yogyakarta: Genta Publishing, 2011. hlm. 60-61. 
Utilitarians yang menyatakan bahwa tujuan pemidanaan harus menimbulkan konsekuensi bermanfaat yang dapat dibuktikan dan pandangan retributivist yang menyatakan bahwa keadilan dapat dicapai apabila tujuan yang Theological tersebut dilakukan dengan menggunakan ukuran prinsip-prinsip keadilan. ${ }^{24}$ Pemidanaan hanya dibenarkan apabila memberikan harapan agar tidak terjadi kejahatan yang lebih besar. Adapun maksimalnya adalah dengan memperbesar kegunaan, manfaat, dan keuntungan yang dihasilkan oleh perbuatan yang akan dilakukan. Diversi akan memberikan keuntungan pada anak. Diversi bertujuan menghindarkan anak dari penerapan hukum pidana demi melindungi kepentingan anak di masa depan.

Artinya secara keseluruhan konsep diversi adalah mengejar dari kemanfaatan dari pemidanaan sesuai dengan pemidanaan Utilitarians dimana pemidanaan harus menimbulkan konsekuensi bermanfaat. Untuk teori tujuan sendiri memandang sebagaimana sesuatu yang dapat digunakan untuk mencapai pemanfaatan, baik yang berkaitan dengan orang yang bersalah maupun yang berkaitan dengan dunia luar, misalnya dengan mengisolasi dan memperbaiki penjahat atau mencegah penjahat potensial, akan menjadikan dunia tempat yang lebih baik. ${ }^{25}$ Pandangan ini jika dikaitkan dengan tujuan diversi itu sendiri ialah menghindarkan anak dari stigma jahat (label jahat), dan dengan tidak adanya stigma jahat berarti turut melindungi mental anak untuk berperilaku layaknya penjahat sehingga potensi kembali berbuat jahat kembali dapat diminimalisasi.

Konsep diversi memuat tujuan pemidanaan secara khusus yakni untuk mencegah anak berbuat kembali tindak pidana ini ditandai dengan adanya syarat diversi yang salah satunya bukanlah tindak pidana pengulangan. Namun tidak memuat pencegahan tindak pidana secara umum karena diversi pada dasarnya untuk menjaga mental anak. Teori gabungan adalah kombinasi dari teori relatif. Teori gabungan (integratif) mendasarkan pidana pada asas pembalasan dan asas tertib pertahanan tata tertib masyarakat, dengan kata lain dua alasan itu menjadi dasar dari penjatuhan pidana. Pada dasarnya teori gabungan adalah gabungan teori absolut dan teori relatif. Gabungan kedua teori itu mengajarkan bahwa penjatuhan hukuman adalah untuk mempertahankan tata tertib hukum dalam masyarakat dan memperbaiki pribadi si penjahat. ${ }^{26}$

24 Muladi, Lembaga Pidana Bersyarat. Bandung: Alumni, 1985, hlm. 49.

25 Muladi dan Barda Nawawi Arief. Teori-Teori dan Kebijakan Pidana. Bandung: Alumni, 1992, hlm. 18.

26 Leden Marpaung. Asas-Teori-Praktek Hukum Pidana. Jakarta: Sinar Grafika, 2009. hlm. 105. 
Menurut Pellegrino Rossi dalam bukunya "Traite de Droit Penal” yang ditulis pada Tahun 1828 menyatakan: Sekalipun pembalasan sebagai asas dari pidana bahwa beratnya pidana tidak boleh melampaui suatu pembalasan yang adil, namun pidana mempunyai berbagai pengaruh antara lain perbaikan sesuatu yang rusak dalam masyarakat dan prevensi general. ${ }^{27}$ Pada dasarnya teori gabungan adalah gabungan teori absolut dan teori relatif. Gabungan kedua teori itu mengajarkan bahwa penjatuhan hukuman adalah untuk mempertahankan tata tertib hukum dalam masyarakat dan memperbaiki pribadi si penjahat. ${ }^{28}$ Pada hakikatnya pidana selalu melindungi masyarakat dan pembalasan atas perbuatan tidak taat hukum. Pidana diharapkan sebagai suatu yang akan membawa kerukunan serta sebagai suatu proses pendidikan untuk menjadikan orang dapat diterima kembali dalam masyarakat.

Diperlukan pendekatan multi dimensional yang bersifat mendasar terhadap dampak pemidanaan, baik yang menyangkut dampak yang bersifat individual maupun dampak yang bersifat sosial. ${ }^{29}$ Pendekatan semacam ini mengakibatkan adanya keharusan untuk memilih teori integratif tentang tujuan pemidanaan, yang dapat memenuhi fungsinya dalam rangka mengatasi kerusakan-kerusakan yang diakibatkan oleh tindak pidana. Konsep diversi mendekati makna pemidanaan integratif yang mengedepankan pemidanaan dengan pendekatan dan aplikasi diversi pada anak yang berkonflik dengan hukum ialah mengejar dari kemanfaatan pemidanaan sesuai dengan pemidanaan Utilitarians dimana pemidanaan haruslah menimbulkan konsekuensi bermanfaat dan berpatokan pada kepentingan terbaik anak sebagai generasi penerus bangsa. Pada kesepakatan diversi terdapat bentuk pemidanaan terhadap anak yang dianggap setara dengan keadaan anak seperti pengembalian ganti rugi terhadap korban dan diikutsertakan dalam lembaga pendidikan atau pelatihan selama 3 bulan. ${ }^{30}$ Pidana pelayanan masyarakat merupakan pidana yang dimaksudkan untuk mendidik anak dengan meningkatkan kepeduliannya pada kegiatan kemasyarakatan yang positif. ${ }^{31}$

Prinsip yang terkandung dalam diversi sebagai jalan untuk mencari keadilan terhadap anak karena landasan awalnya konsep diversi merupakan bagian dari konsep perlindungan anak dengan mengedepankan kepentingan terbaik anak. Diversi dilandasi

\footnotetext{
27 Muladi dan Barda Nawawi Arief, Op.Cit., hlm. 19.

28 Adami Chazawi. Pelajaran Hukum Pidana I, Jakarta: PT. Raja Grafindo, 2010. hlm. 162-163.

29 Muladi dan Barda Nawawi Arief, Op.Cit., hlm. 53.

30 Pasal 10 dan Pasal 11 Undang-Undang Sistem Peradilan Pidana Anak.

31 Pasal 76 Undang-Undang Sistem Peradilan Pidana Anak.
} 
prinsip non diskriminasi berkaitan erat dengan konsep perlindungan anak. Dimana perlindungan anak ${ }^{32}$ merupakan segala kegiatan untuk menjamin dan melindungi anak dan hak haknya agar tetap hidup, tumbuh dan berkembang dan berpartisipasi secara optimal sesuai dengan harkat dan martabat kemanusiaan serta mendapat perlindungan dari kekerasan dan diskriminasi. Secara keseluruhan diversi merupakan bagian dari konsep pemidanaan dengan berlandaskan pada prinsip perlindungan anak.

Maka terhadap diversi dengan prinsip perlindungan anak dalam hal menangani anak yang berkonflik dengan hukum sebaiknya tidak mengedepankan syarat diversi yang dimana diversi hanya akan dilakukan ketika ancaman pidananya di bawah 7 Tahun (Pasal 7 ayat 2 huruf b) Undang-Undang Sistem Peradilan Pidana Anak. Tetapi terlebih dahulu mempertimbangkan keadaan anak, korban, efek dari perbuatan anak itu sendiri dimasa yang akan datang. Karena anak yang melakukan tindak pidana dengan ancaman di atas 7 tahun justru merupakan anak yang paling terpengaruh oleh lingkungannya dalam Teori Association deferential oleh E. Shutherland menyatakan bahwa anak yang menjadi pelanggar aturan karena partisipasinya di tengah-tengah lingkungan sosialnya. ${ }^{33}$ Partisipasi anak dalam lingkungan sosialnya dengan keadaan anak yang belum mampu mempertimbangkan baik buruknya suatu perbuatan dan akibat perbuatannya menyebabkan anak berkonflik dengan hukum.

Penerapan prinsip diversi adalah upaya untuk melindungi kepentingan anak hal ini sejalan dengan Penerapan prinsip-prinsip penting yang termuat di dalam The Beijing Rules yang dan adanya pasal yang menyebutkan bahwa dalam Sistem Peradilan pidana anak sebagaimana dimaksud pada ayat (2) huruf a dan b wajib diupayakan diversi Pasal 5 Ayat (3) Undang-Undang Sistem Peradilan Pidana Anak yang menyatakan; Dalam Sistem Peradilan Pidana Anak sebagaimana dimaksud pada ayat (2) huruf a dan huruf b wajib diupayakan Diversi. Frasa wajib dalam ketentuan ini harus dimaknai sebagai penekanan untuk selalu mengedepankan upaya diversi pada setiap perkara yang melibatkan anak sebagai pelaku.

Pedoman The United Nations Standard Minimum Rules for Administration of Juvenile Justice (the Beijing Rules) yang disahkan melalui Resolusi Majelis PBB No. 40/33 Tanggal 29 November 1985, maka tujuan dari peradilan anak sebagaimana disebutkan dalam Rule

32 Pasal 1 ayat 2 Undang-Undang 35 Tahun 2014 Tentang Perubahan Atas Undang-Undang Nomor 23 Tahun 2002 Tentang Perlindungan Anak.

33 Liza Agnesta Krisna. Hukum Perlindungan Anak (Panduan Memahami Anak yang Berkonflik dengan Hukum). Yogyakarta: Deepublish, 2018. hlm. 59. 
5.1 adalah "The juvenile justice system shall emphasize the well-being of the juvenile and shall ensure that any reaction to juvenile offenders shall always be in proportion to the circumstances of both the offenders and the offence" (Sistem peradilan anak harus lebih menekankan pada kesejahteraan anak dan harus dipastikan bahwa seluruh penanganan terhadap anak harus selalu sesuai dengan keadaan, baik keadaan dari pelaku maupun keadaan dari pelanggaran/kejahatan). ${ }^{34}$

Ketentuan ini menggambarkan betapa pentingnya kesejahteraan anak dan ketika anak melakukan tindak pidana harus ketentuan penanganannya harus selalu disesuaikan dengan keadaan anak. Berkaitan dengan tujuan tersebut, maka ada satu model penyelesaian perkara pidana anak tanpa harus melalui proses peradilan, sebagaimana diatur dalam Rule. 11 The Beijing Rules yang berbunyi: 11.1 Consideration shall be given, wherever appropriate, to dealing with juvenile offenders without resorting to formal trial by the competent authority, referred to in rule 14.1 below; (Pertimbangan harus diberikan kapan saja diperlukan untuk menangani anak tanpa harus menyerahkannya pada pengadilan formal oleh lembaga yang berwenang, seperti yang diatur dalam aturan 14.1 di bawah). Pertimbangan untuk menyelesaikan perkara pada anak yang berkonflik dengan hukum di luar peradilan harus selalu diberikan kepada anak dengan landasan pada perlindungan kepada anak sebagai generasi penerus. Pada dasarnya awal terbentuknya konsep diversi dilandasi pada prinsip perlindungan anak.

\section{KESIMPULAN}

1. Prinsip yang terkandung dalam diversi sebagai jalan untuk mencari keadilan terhadap anak karena landasan awalnya konsep diversi merupakan bagian dari konsep perlindungan anak dengan mengedepankan kepentingan terbaik anak. Diversi dilandasi prinsip non diskriminasi berkaitan erat kaitannya dengan konsep perlindungan anak. Konsep diversi sesuai dengan pemidanaan Utilitarians dimana pemidanaan harus menimbulkan konsekuensi bermanfaat. Pemidanaan dalam konsep diversi haruslah menjadi solusi terbaik dan menimbulkan kemanfaatan terhadap anak. Maka sejalan dengan hal tersebut prinsip-prinsip yang termuat di dalam The Beijing Rules dan Pasal 5 Ayat (3) Undang-Undang Sistem Peradilan Pidana Anak yang mewajibkan adanya upaya

34 Achmad Ratomi. Konsep Prosedur Pelaksanaan Diversi Pada Tahap Penyidikan Dalam Penyelesaian Tindak Pidana Yang Dilakukan Oleh Anak. Volume 6, Nomor 3, Desember 2013. hlm. 290-452. 
diversi pada setiap anak yang berkonflik dengan hukum. Oleh karenanya terhadap upaya diversi pada anak yang berkonflik dengan hukum sebaiknya tidak mengedepankan syarat diversi yang dimana diversi hanya akan dilakukan ketika ancaman pidananya di bawah 7 tahun.

\section{Daftar Pustaka}

\section{Buku}

Abidin, Zainal. Analisis Eksistensial. Jakarta: Raja Grafindo Persada. 2007.

Adi, Koesno. Diversi Tindak Pidana Narkotika Anak. Malang: Setara Press, 2014.

Bynum, J. E. and W. E. Thompson, Juvenile Delinquency: A Sociological Approach (3rd. ed.). Needham Heights, MA: Allyn and Bacon. 1996.

Chazawi, Adami, Pelajaran Hukum Pidana I, Jakarta: PT. Raja Grafindo, 2010.

Effendi, Erdianto, Hukum Pidana Indonesia. Bandung: PT Refika Aditama, 2011.

Folk, Kenneht, Early Intervention, Diversion and Youth Conferencing, A National Review of Current Approach to Diverting Juvenile from the Criminal Justice System. Canberra: Commonwealth of Australia. Government Attorney-general's Departement. 2003.

Krisna, Liza Agnesta. Hukum Perlindungan Anak (Panduan Memahami Anak yang Berkonflik dengan Hukum). Yogyakarta: Deepublish, 2018.

Lamintang, P.A.F. dan Theo Lamintang. Kejahatan Terhadap Nyawa, Tubuh, dan Kesehatan. Jakarta: Sinar Grafika, 2012.

M. Nasir Djamil. Anak Bukan Untuk Dihukum Catatan Pembahasan Undang-Undang Sistem Peradilan Pidana Anak (UU-SPPA), Jakarta: Sinar Grafika, 2013.

Marlina. Diversi dan Restorative Justice Sebagai Alternatif Perlindungan Terhadap Anak Yang Berhadapan Dengan Hukum. Medan: Pusat kajian dan Perlindungan Anak, PKPA, 2007.

Pengantar Konsep Diversi dan Restorative Justice dalam Hukum Pidana, Medan: USU Press. 2010.

Marpaung, Leden, Asas-Teori-Praktek Hukum Pidana. Jakarta: Sinar Grafika, 2009.

Marzuki, Peter Mahmud. Penelitian Hukum. Jakarta: Kencana, 2008.

Moeljatno. Asas-Asas Hukum Pidana (Edisi Revisi), Jakarta: Rineka Cipta, 2015.

Muladi dan Barda Nawawi Arief. Teori-Teori dan Kebijakan Pidana. Bandung: Alumni, 1992.

Muladi, Lembaga Pidana Bersyarat. Bandung: Alumni, 1985. 
Nashriana. Perlindungan Hukum Pidana Bagi Anak di Indonesia. Jakarta: PT. Grafindo Persada, 2011.

Pramukti, Angger Sigit \& Fuady Primaharsya. Sistem Peradilan Pidana Anak. Jakarta: Media Pressindo. 2018.

Robert \& Keith Haley. Introduction Criminal Justice. Callifornia-USA: Glencoe McGraw Hill, 2002.

Setiady, Tolib. Pokok-Pokok Hukum Penintesier Indonesia. Bandung: Alfabeta. 2010.

Wadong, Maulana Hassan. Advokasi dan Hukum perlindungan Anak. Jakarta: PT Gramedia Widiasarana Indonesia, 2000.

Wahyudi, Setya. Implementasi Ide Diversi Dalam Pembaharuan Sistim Peradilan Pidana Anak di Indonesia. Yogyakarta: Genta Publishing, 2011.

\section{Jurnal}

Haris, Oheo K., Victim's Involvement Model in Children Legal Process Based on Law No. 11/2012 on Children Criminal Justice System. Yuridika. Fakultas Hukum Universitas $\begin{array}{llllll}\text { Airlangga. } & \text { Volume } & 34 & \text { No. } & 1 . & 2019 .\end{array}$ journal.unair.ac.id/YDK/article/view/7943, diakses pada tanggal 8 Mei 2019.

Ratomi, Achmad, Konsep Prosedur Pelaksanaan Diversi Pada Tahap Penyidikan Dalam Penyelesaian Tindak Pidana Yang Dilakukan Oleh Anak. Volume 6, Nomor 3, Desember 2013.

Singh, B. and Precious Nolwazi Ntuli. Diversion Programmes: Case Studies of the Youth Empowerment Scheme Programme at NICRO. Durban, South Africa, The Oriental Anthropologist, Vol. 17, No. 2, 2017. 